УДК 332.1

Вахович I.M., д.е.н., професор

Vakhovych I. Doctor of Economic Sciences, Professor http://orcid.org/0000-0003-1129-203X

Камінська I.M., к.е.н., доцент

Kaminska I. Candidate of Economic Sciences, Associate Professor https://orcid.org/0000-0001-6181-7522

Недопад Г.В., аспірант

Nedopad H. Postgraduate Student

\title{
ВОЛИНСЬКА ОБЛАСТЬ У ПЛОЩИНІ СОЦІАЛЬНО-ЕКОНОМІЧНОГО РОЗВИТКУ УКРАЇНИ
}

\author{
Луцький національний технічний університет
}

У статті проаналізовано основні показники соціально-економічного розвитку Волинської області та здійснено їх порівняльний аналіз із показниками за іншими регіонами України. Встановлено, що Волинська область $\epsilon$ регіоном із середнім рівнем соціально-економічного розвитку з тенденцією до його зниження. Доведено, що, в умовах високого рівня регіональної диференціації в Україні, середні значення показників соціально-економічного розвитку регіонів $є$ недостатніми для капіталізації економіки, забезпечення належного рівня добробуту й якості життя населення.

Також проаналізовано місце Волинської області у різноманітних регіональних рейтингах, що достатньо переконливо демонструють місце регіону в соціально-економічному розвитку України.

Результати моніторингу соціально-економічного розвитку регіонів показали, що прийняті у Волинській області управлінські рішення були недостатньо ефективними й дієвими, а тому існує потреба їх коригування та і загалом оновлення моделей стратегічного планування й управління в регіоні.

Результати регіонального рейтингу ведення бізнесу показали наявність проблемних моментів взаємодії суб'єктів господарювання із місцевими органами влади у Волинській області, адже фактично область набрала лише 50,8\% балів з можливих і лише за рахунок того, що в інших регіонах держави ситуація була ще гіршою, зайняла 8-у позицію в такому рейтингу. Це підтверджує недостатньо сприятливі умови й неналежний бізнес-клімат для розвитку малого та середнього підприємництва в регіонах України загалом.

Згідно результатів рейтингу інвестиційної ефективності областей України, Волинська область значно поліпшила свої позиції порівняно з 2016 роком. Високі бали Волинської області у I кварталі 2018 року свідчать про потенціал регіону для підвищення інвестиційної ефективності.

У рейтингу областей України за успіхами в євроінтеграції, Волинська область увійшла до шестірки регіонів із найвищими балами. Хоча реально Волинська область набрала лише 50,9\% від максимально можливого рівня балів, що засвідчує в цілому низьку активність регіонів України у процесах європейської інтеграції, нереалізованість потенціалу Волинської області у даному напрямі та упущені нею можливості на рівні близько $50 \%$.

За результатами моніторингу процесу децентралізації та реформування місцевого самоврядування, Волинська область у рейтингу областей щодо формування спроможних громад станом на 10 січня 2020 рік зайняла 6 місце.

Загалом Волинська область згідно розглянутих регіональних рейтингів займає в середньому вищі від середнього позиції серед регіонів України. Разом з тим, результати проведеного аналітичного дослідження продемонстрували нестабільність соціально-економічного розвитку Волинської області та нестійкі їі позиції в рейтингових таблицях.

Отримані результати можуть бути використані під час формування стратегії соціальноекономічного розвитку Волинської області та прогнозування показників на середньо- і довгострокову перспективу.

Ключові слова: регіон, сочіально-економічний розвиток, національна економіка.

\section{VOLYN REGION IN THE PLANE OF SOCIO-ECONOMIC DEVELOPMENT OF UKRAINE}

\section{Lutsk National Technical University}

The main indicators of socio-economic development of Volyn region are analyzed in the article. The comparative analysis of the main socio-economic indicators was carried out between the Volyn region and 
others regions of Ukraine. It is established that the Volyn region is a region with an average level of socioeconomic development with decreasing tendency. It is proved that, in the conditions of high-level of regional differentiation in Ukraine, the average values of indicators of socio-economic development of regions are insufficient for regional economy capitalization, for ensuring the proper welfare level and for improving quality of life of the population.

The position of Volyn region among other Ukrainian regions in various regional rankings was also analyzed. The results of the rankings strongly demonstrate the Volyn region's place in the socio-economic development of Ukraine.

The results of Monitoring the socio-economic development of regions showed that the management decisions wich had been taken in the Volyn region were not efficient and effective enough. Therefore, there is a need to correct such decisions and to update strategic planning and management models in Volyn region in general.

Analysis of the results of Regional Doing Business Ranking showed the problematic moments in interaction between busuness entities and local authorities in Volyn region, because in fact the Volyn region scored only $50,8 \%$ of the possible points, and only due to the fact that in other regions of the state the situation was even worse, Volyn region took the 8th position in this rating. This confirms not a favorable conditions and the poor business climate for the development of small and medium-sized businesses in the regions of Ukraine as a whole.

According to Regional investment efficiency ranking, Volyn region has significantly improved its position in the ranking compared to its position in 2016. The high points of Volyn region in Q1 2018 indicate the potential of the region for improving the investment efficiency.

According to Rating of European Integration of Regions, Volyn region is one of the six regions with the highest scores. Although realistically, the Volyn region received only 50,9\% of the maximum possible points. All this demonstrates the overall low activity of the regions of Ukraine in the processes of European integration, unrealized potential of Volyn region in this direction and it's missed opportunities (about 50\%).

Based on results of Monitoring of the process of power decentralisation and local governance reform, Volyn region gets good marks in the rating for the formation of able communities as of 10 January 2020 (ranked 6th).

In general, according to the regional ratings, Volyn region occupies the higher than the average position among Ukrainians regions. At the same time, the results of the analytical study showed instability in socioeconomic development of Volyn region and its unstable positions in the ranking tables.

The obtained results can be applied when making a strategy of socio-economic development of Volyn region and when making a forecast of indicators in the medium and long term.

Keywords: region, socio-economic development, national economy.

Постановка проблеми у загальному вигляді i iї зв'язок 3 важливими науковими та практичними завданнями. 3 переміщенням епіцентру соціальноекономічних перетворень на регіональний рівень, посилюється увага до регіональної проблематики та актуалізується потреба системної і об’єктивної кількісної характеристики параметрів соціально-економічної системи регіону, а також комплексних досліджень місця й рейтингу кожного з регіонів в національній економіці України. Тому закономірним і очевидним $\epsilon$ інтерес до вивчення особливостей соціально-економічного розвитку кожного регіону України в національній площині.

Визначення місця кожного регіону в системі міжрегіональних і вертикальних економічних зав'язків $є$ вихідним моментом формування та реалізації адекватної ефективної політики й стратегії соціально-економічного розвитку на різних рівнях. Очевидно, що глобальні цілі політики та стратегії забезпечення соціальноекономічного розвитку такі як, розвиток економіки, поліпшення рівня життя населення, охорона навколишнього середовища $є$ спільними для всіх регіонів держави, але стратегічні вектори і пріоритети, шляхи й методи досягнення цих цілей будуть різними для різних регіонів, виходячи із вихідних умов кожного конкретного регіону, а саме рівня забезпеченості ресурсами, поточної соціально-економічної ситуації, ендогенного потенціалу розвитку тощо.

Аналіз останніх досліджень, у яких започатковано вирішення проблеми. Проблематика методології дослідження, діагностики, управління i забезпечення соціально-економічного розвитку регіонів України достатньо активно піднімається вітчизняними науковцями-економістами. Зокрема, значну увагу даним питанням у 
своїх працях приділили такі вчені, як Абалкін Л.І., Бутко М.П., Гейць В.М., Данилишин Б.М., Долішній М.І., Дорогунцов С.І., Заставний Ф.Д., Мунтіян В.І., Стеченко Д.М., Шевчук Л.Т. та багато інших. Проте, сьогодні перед регіонами України постають якісно нові проблеми соціально-економічної нерівномірності, регіональних асиметрій, децентралізації, глобалізації та інтеграційних процесів. Таким чином, варто відзначити необхідність поглиблення досліджень та організації аналізу сучасного рівня соціальноекономічного розвитку регіонів як передумови формування і реалізації оптимальної стратегії їх розвитку, модернізації моделей регіонального розвитку, підвищення ефективності державної регіональної політики та внутрішньої політики регіонів.

Цілі статті. Цілями статті $є$ системне порівняльне кількісне дослідження параметричних характеристик й індикаторів соціально-економічного розвитку Волинської області у площині соціально-економічного розвитку України.

Виклад основного матеріалу дослідження 3 повним обгрунтуванням отриманих наукових результатів. Комплексний аналіз поточної соціальноекономічної ситуації в регіоні дозволяе виявити динаміку, тренди, особливості та проблеми регіонального розвитку. Тому проаналізуємо основні показники соціальноекономічного розвитку на прикладі Волинської області та порівняємо їх із показниками за іншими регіонами України (табл. 1).

Як засвідчують офіційні дані Державної служби статистики України, у державі спостерігалась тенденція зростання в ключових сферах соціально-економічного розвитку, адже:

- нарощено обсяги ВРП у розрахунку на одну особу;

- збільшено обсяги капітальних інвестицій та прямих інвестицій у розрахунку на одну особу, що залучаються в економіки регіонів;

- знижено рівень інфляції;

- скорочено частку населення із середньодушовими еквівалентними грошовими доходами на місяць нижче прожиткового мінімуму;

- забезпечено ріст рівня наявного доходу у розрахунку на одну особу та середньомісячної номінальної заробітної плати працівників;

- підвищено рівень забезпеченості населення житлом;

- збільшено обсяги експорту у розрахунку на одну особу;

- нарощено обсяги доходів місцевих бюджетів (без міжбюджетних трансфертів) у розрахунку на одну особу;

- нарощено обсяги доходів суб'єктів господарювання у розрахунку на одну особу;

- знижено рівень безробіття населення.

Попри такі результати також відмітилась тенденція посилення рівня диференціації між регіонами України за більшістю показників, тобто в соціальноекономічному просторі країни зберігаються центр-периферійні відносини.

Таблиця 1

Порівняльний аналіз основних показників соціально-економічного розвитку

Волинської області

\begin{tabular}{|c|c|c|c|c|c|c|c|c|c|}
\hline \multirow[b]{2}{*}{ Показники } & \multirow[b]{2}{*}{ Роки } & \multirow[b]{2}{*}{$\begin{array}{c}\text { Середнє } \\
\text { значення } \\
\text { в Україні }\end{array}$} & \multirow{2}{*}{$\begin{array}{c}\text { Максимальне } \\
\text { значення серед } \\
\text { регіонів } \\
\text { України - max }\end{array}$} & \multirow[b]{2}{*}{$\begin{array}{c}\text { Мінімальне } \\
\text { значення серед } \\
\text { регіонів } \\
\text { України - min }\end{array}$} & \multirow[b]{2}{*}{$\max / \min$} & \multirow[b]{2}{*}{$\begin{array}{c}\text { Волинська } \\
\text { обл. }\end{array}$} & \multicolumn{3}{|c|}{$\begin{array}{c}\text { Значення показника у } \\
\text { Волинській обл. }\end{array}$} \\
\hline & & & & & & & \begin{tabular}{|c|} 
у \% до \\
середнього \\
значення в \\
Україні \\
\end{tabular} & $\begin{array}{l}\text { у \% до } \\
\min \end{array}$ & $\begin{array}{l}\text { y } \% \text { до } \\
\max \end{array}$ \\
\hline 1 & 2 & 3 & 4 & 5 & 6 & 7 & 8 & 9 & 10 \\
\hline \multirow{3}{*}{$\begin{array}{l}\text { 1. ВРП у } \\
\text { розрахунку } \\
\text { на одну } \\
\text { особу, грн. }\end{array}$} & 2015 & 46413 & $\begin{array}{l}155904 \\
\text { (м. Київ) }\end{array}$ & $\begin{array}{c}10778 \\
\text { (Луганська обл.) }\end{array}$ & 14,47 & 30387 & 65,5 & 281,9 & 19,5 \\
\hline & 2016 & 55899 & $\begin{array}{l}191736 \\
\text { (м. Київ) }\end{array}$ & $\begin{array}{c}14251 \\
\text { (Луганська обл.) }\end{array}$ & 13,45 & 34310 & 61,4 & 240,8 & 17,9 \\
\hline & 2017 & 70233 & 238622 & 13883 & 17,19 & 49987 & 71,2 & 360,1 & 20,9 \\
\hline
\end{tabular}


(м. Київ)

Продовж. табл. 1

\begin{tabular}{|c|c|c|c|c|c|c|c|c|c|}
\hline 1 & 2 & 3 & 4 & 5 & 6 & 7 & 8 & 9 & 10 \\
\hline \multirow{4}{*}{\begin{tabular}{|l|} 
2. Індекс \\
споживчих цін \\
(грудень до грудня \\
попереднього \\
року), \%
\end{tabular}} & 016 & 112,4 & $\begin{array}{c}\text { 114,2 (Полтавська } \\
\text { та Сумська обл.) }\end{array}$ & $\begin{array}{c}110,0 \\
\text { (Вінницька обл.) }\end{array}$ & 1,04 & 111,8 & 99,5 & 101,6 & 97,9 \\
\hline & 2017 & 113,7 & $\begin{array}{c}115,9 \\
\text { (Донецька обл.) }\end{array}$ & $\begin{array}{c}112,4 \\
\text { (Чернівецька обл.) }\end{array}$ & 1,03 & 114,6 & 100,8 & 102,0 & 98,9 \\
\hline & 2018 & 109,8 & $\begin{array}{c}112,3 \\
\text { (Донецька обл.) }\end{array}$ & $\begin{array}{c}108,7 \\
\text { (Чернівецька обл.) }\end{array}$ & 1,03 & 109,9 & 100,1 & 101,1 & 97,9 \\
\hline & 2019 & 104,1 & $\begin{array}{c}106,0 \\
\text { (Донецька обл.) }\end{array}$ & $\begin{array}{c}102,4 \\
\text { (Вінницька обл.) }\end{array}$ & 1,04 & 104,9 & 100,8 & 102,4 & 99,0 \\
\hline \multirow{3}{*}{$\begin{array}{l}\text { 3. Капітальні } \\
\text { інвестиції на одну } \\
\text { особу, грн. }\end{array}$} & 2016 & 8451,6 & $\begin{array}{c}36974,2 \\
\text { (м. Київ) } \\
\end{array}$ & $\begin{array}{c}1877,4 \\
\text { (Луганська обл.) }\end{array}$ & 19,69 & 6144,0 & 72,7 & 327,3 & 16,6 \\
\hline & 2017 & 0598,0 & $\begin{array}{l}47093,3 \\
\text { (м. Київ) } \\
\end{array}$ & $\begin{array}{c}1529,6 \\
\text { (Луганська обл.) }\end{array}$ & 30,79 & 6790,8 & 64,1 & 444,0 & 14,4 \\
\hline & 2018 & 13746,4 & $\begin{array}{l}\text { 69039,4 } \\
\text { (м. Київ) }\end{array}$ & $\begin{array}{c}1493,7 \\
\text { (Луганська обл.) }\end{array}$ & 46,22 & 8400,1 & 61,1 & 562,4 & 12,2 \\
\hline \multirow{3}{*}{\begin{tabular}{|l|} 
4. Прямі інвестиції \\
(акціонерний \\
капітал) на одну \\
особу населення, \\
дол. США
\end{tabular}} & 2016 & 734,8 & $\begin{array}{c}5745,3 \\
\text { (м. Київ) } \\
\end{array}$ & $\begin{array}{c}45,5 \\
\text { (Тернопільська обл.) } \\
\end{array}$ & 126,27 & 236,9 & 32,2 & 520,7 & 4,1 \\
\hline & 2017 & 746,9 & $\begin{array}{c}5657,6 \\
\text { (м. Київ) }\end{array}$ & $\begin{array}{c}42,7 \\
\text { (Тернопільська обл.) }\end{array}$ & 132,50 & 242,3 & 32,4 & 567,4 & 4,3 \\
\hline & 2018 & 767 & $\begin{array}{c}5828,4 \\
\text { (м. Київ) }\end{array}$ & \begin{tabular}{|c|}
48,8 \\
(Чернівецька обл.) \\
\end{tabular} & 119,43 & 251,0 & 32,7 & 14,3 & 4,3 \\
\hline \multirow{3}{*}{$\begin{array}{l}\text { 5. Середній рівень } \\
\text { наявного доходу у } \\
\text { розрахунку на } \\
\text { одну особу, грн. }\end{array}$} & 2016 & 7079,9 & $\begin{array}{l}92253,6 \\
\text { (м. Київ) }\end{array}$ & $\begin{array}{c}13792,7 \\
\text { (Луганська обл.) }\end{array}$ & 6,69 & 30012,5 & 80,9 & 217,6 & 32,5 \\
\hline & 2017 & 77269,7 & $\begin{array}{l}118207,6 \\
\text { (м. Київ) }\end{array}$ & $\begin{array}{c}16416,4 \\
\text { (Луганська обл.) }\end{array}$ & 7,20 & 38514,0 & 81,5 & 234,6 & 32,6 \\
\hline & 2018 & 7908,6 & $\begin{array}{l}141173,8 \\
\text { (м. Київ) }\end{array}$ & $\begin{array}{c}20618,6 \\
\text { (Луганська обл.) }\end{array}$ & 6,85 & 46475,1 & 80,3 & 225,4 & 32,9 \\
\hline \multirow{3}{*}{\begin{tabular}{|l|} 
6. Частка \\
населення із \\
середньодушови- \\
ми еквівалентними \\
грошовими \\
доходами на \\
місяць нижче \\
прожиткового \\
мінімуму, \% \\
\cline { 2 - 3 }
\end{tabular}} & 2016 & 10,2 & $\begin{array}{c}23,5 \\
\text { (Волинська обл.) }\end{array}$ & \begin{tabular}{|c|}
3,8 \\
(Миколаївська обл.) \\
\end{tabular} & 6,18 & 23,5 & 230,4 & 18,4 & 100,0 \\
\hline & 2017 & 6,8 & $\begin{array}{c}18,1 \text { (Житомирська } \\
\text { обл.) }\end{array}$ & $\begin{array}{c}2,2 \\
\text { (Полтавська та } \\
\text { Івано-Франківська } \\
\text { обл.) } \\
\end{array}$ & 8,23 & 10,1 & 148,5 & 459,1 & 55,8 \\
\hline & 2018 & 4,3 & $\begin{array}{c}10,7 \\
\text { (Вінницька обл.) }\end{array}$ & $\begin{array}{c}\text { 0,2 (Полтавська та } \\
\text { Івано-Франківська } \\
\text { обл.) } \\
\end{array}$ & 53,50 & 9,9 & 230,2 & 4950,0 & 92,5 \\
\hline \multirow{3}{*}{\begin{tabular}{|l|} 
7. Середній рівень \\
витрат населення у \\
розрахунку на \\
одну особу, грн.
\end{tabular}} & 2016 & 6 & $\begin{array}{l}105214,0 \\
\text { (м. Київ) }\end{array}$ & $\begin{array}{c}12754,2 \\
\text { (Луганська обл.) }\end{array}$ & 25 & 6 & 88,7 & 3 & 39,9 \\
\hline & 2017 & 1102,3 & $\begin{array}{l}133534,7 \\
\text { (м. Київ) } \\
\end{array}$ & $\begin{array}{c}16248,2 \\
\text { (Луганська обл.) } \\
\end{array}$ & 8,22 & 56592,3 & 92,6 & 348,3 & 42,4 \\
\hline & 2018 & 5769,2 & $\begin{array}{l}174823,8 \\
\text { (м. Київ) }\end{array}$ & $\begin{array}{c}\text { 19176,8 } \\
\text { (Закарпатська обл.) }\end{array}$ & 9,12 & 63759,3 & 84,1 & 332,5 & 36,5 \\
\hline \multirow{4}{*}{\begin{tabular}{|l|} 
8. Середньомісячна \\
номінальна \\
заробітна плата \\
працівників, грн.
\end{tabular}} & 2016 & 183 & 48 (м. Київ) & $\begin{array}{c}3695 \text { (Тернопільська } \\
\text { обл.) }\end{array}$ & 3 & 4047 & 78,1 & 109,5 & 46,8 \\
\hline & 2017 & 7104 & 135 (м. Київ) & \begin{tabular}{|c|}
5554 (Тернопільська \\
обл.)
\end{tabular} & 00 & 5849 & 82,3 & 105,3 & 52,5 \\
\hline & 2018 & 8865 & 13542 (м. Київ) & \begin{tabular}{|c|}
6969 (Тернопільська \\
обл.)
\end{tabular} & ,94 & 7324 & 82,6 & 105,1 & 54,1 \\
\hline & $\begin{array}{l}\text { гру- } \\
\text { день }\end{array}$ & 2264 & 18869 (м. Київ) & $\begin{array}{c}8851 \text { (Чернігівська } \\
\text { обл.) }\end{array}$ & 2,13 & 10333 & 84,3 & 116,7 & 54,8 \\
\hline \multirow{3}{*}{ 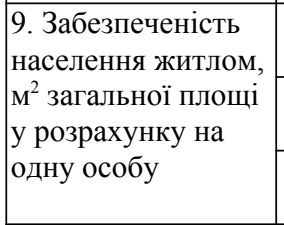 } & 2016 & J, & $\begin{array}{c}\text { 35,89 (Київська } \\
\text { обл.) }\end{array}$ & 59 (Луганська обл.) &, 10 & 23,01 & 99,8 & 267,9 & 64,1 \\
\hline & 2017 & 3,23 & $\begin{array}{c}35,77 \text { (Київська } \\
\text { обл.) }\end{array}$ & 8,66 (Луганська обл.) & 4,13 & 23,46 & 101,0 & 270,9 & 65,6 \\
\hline & 2018 & 56 & $\begin{array}{l}36,17 \text { (Київська } \\
\text { обл.) }\end{array}$ & 8,74 (Луганська обл.) & 4,14 & 23,87 & 101,3 & 273,1 & 66,0 \\
\hline \multirow{3}{*}{\begin{tabular}{|l|} 
10. Обсяг доходів \\
місцевих бюджетів \\
(без \\
міжбюджетних \\
трансфертів), грн./ \\
\end{tabular}} & 2016 & 4026 & $\begin{array}{c}10147 \\
\text { (м. Київ) }\end{array}$ & $\begin{array}{c}1132 \\
\text { (Луганська обл.) } \\
\end{array}$ & 8,96 & 2978 & 74,0 & 263,1 & 29,3 \\
\hline & 2017 & 5414 & $\begin{array}{c}11928 \\
\text { (м. Київ) } \\
\end{array}$ & $\begin{array}{c}1459 \\
\text { (Луганська обл.) } \\
\end{array}$ & 0,10 & 4551 & 84,1 & 311,9 & 38,2 \\
\hline & 2018 & 6251 & 14143 & 1597 & 8,86 & 4838 & 77,4 & 302,9 & 34,2 \\
\hline
\end{tabular}


Продовж. табл. 1

\begin{tabular}{|c|c|c|c|c|c|c|c|c|c|}
\hline 1 & 2 & 3 & 4 & 5 & 6 & 7 & 8 & 9 & 10 \\
\hline \multirow{3}{*}{$\begin{array}{l}\text { 11. Доходи суб’єктів } \\
\text { господарювання, } \\
\text { тис. грн./особу }\end{array}$} & 2016 & 158,06 & $\begin{array}{c}890,49 \\
\text { (м. Київ) }\end{array}$ & $\begin{array}{c}24,51 \\
\text { (Луганська обл.) }\end{array}$ & 36,33 & 112,23 & 71,0 & 457,9 & 12,6 \\
\hline & 2017 & 196,11 & $\begin{array}{l}1103,82 \\
\text { (м. Київ) }\end{array}$ & $\begin{array}{c}20,77 \\
\text { (Луганська обл.) }\end{array}$ & 53,14 & 159,85 & 81,5 & 769,6 & 14,5 \\
\hline & 2018 & 236,44 & $\begin{array}{l}1349,76 \\
\text { (м. Київ) }\end{array}$ & $\begin{array}{c}21,90 \\
\text { (Луганська обл.) }\end{array}$ & 61,63 & 184,04 & 77,8 & 840,4 & 13,6 \\
\hline \multirow{4}{*}{$\begin{array}{l}\text { 12. Рівень безробіття } \\
\text { населення (за } \\
\text { методологією МОП) } \\
\text { у віці } 15-70 \text { років, \% } \\
\text { до економічно } \\
\text { активного населення } \\
\text { відповідного віку }\end{array}$} & 2016 & 9,3 & $\begin{array}{c}16,0 \\
\text { (Луганська обл.) }\end{array}$ & $\begin{array}{c}6,4 \\
\text { (Харківська обл.) }\end{array}$ & 2,50 & 11,5 & 123,7 & 179,7 & 71,9 \\
\hline & 2017 & 9,5 & $\begin{array}{c}16,6 \\
\text { (Луганська обл.) }\end{array}$ & $\begin{array}{c}6,1 \\
\text { (Харківська обл.) } \\
\end{array}$ & 2,72 & 12,5 & 131,6 & 204,9 & 75,3 \\
\hline & 2018 & 8,8 & $\begin{array}{c}15,1 \\
\text { (Луганська обл.) }\end{array}$ & $\begin{array}{c}5,3 \\
\text { (Харківська обл.) }\end{array}$ & 2,85 & 11,4 & 129,5 & 215,1 & 75,5 \\
\hline & \begin{tabular}{|c|}
$01-09$. \\
2019 \\
\end{tabular} & 8,4 & $\begin{array}{c}14,3 \\
\text { (Луганська обл.) }\end{array}$ & $\begin{array}{c}4,9 \\
\text { (Харківська обл.) }\end{array}$ & 2,92 & 10,8 & 128,6 & 220,4 & 75,5 \\
\hline \multirow[t]{3}{*}{$\begin{array}{l}\text { 13. Обсяги експорту, } \\
\text { дол. США / особу }\end{array}$} & 2016 & 857 & $\begin{array}{c}2971 \\
\text { (м. Київ) }\end{array}$ & $\begin{array}{c}132 \\
\text { (Чернівецька } \\
\text { обл.) } \\
\end{array}$ & 22,51 & 589 & 68,7 & 446,2 & 19,8 \\
\hline & 2017 & 1018 & $\begin{array}{c}3319 \\
\text { (м. Київ) }\end{array}$ & $\begin{array}{c}108 \\
\text { (Луганська обл.) }\end{array}$ & 30,73 & 664 & 65,2 & 614,8 & 20,0 \\
\hline & 2018 & 1122 & $\begin{array}{c}3473 \\
\text { (м. Київ) }\end{array}$ & $\begin{array}{c}94 \\
\text { (Луганська обл.) } \\
\end{array}$ & 36,95 & 695 & 61,9 & 739,4 & 20,0 \\
\hline \multirow{3}{*}{$\begin{array}{l}14 . \text { Обсяг } \\
\text { iнноваційних витрат } \\
\text { у розрахунку на } \\
\text { одне підприємство, } \\
\text { тис. грн./од. }\end{array}$} & 2016 & 11,7 & $\begin{array}{c}77,5 \\
\text { (Дніпропетровська } \\
\text { обл.) }\end{array}$ & $\begin{array}{c}0,3 \\
\text { (Рівненська обл.) }\end{array}$ & 258,33 & 3,3 & 28,2 & 1100,0 & 4,3 \\
\hline & 2017 & 7,4 & $\begin{array}{c}30,6 \\
\text { (Сумська обл.) } \\
\end{array}$ & $\begin{array}{c}0,3 \\
\text { (Рівненська обл.) } \\
\end{array}$ & 102,00 & 8,0 & 108,1 & 2666,7 & 26,1 \\
\hline & 2018 & 9,4 & $\begin{array}{c}90,6 \\
\text { (Запорізька обл.) }\end{array}$ & $\begin{array}{c}0,3 \\
\text { (Рівненська обл.) }\end{array}$ & 302,00 & 4,0 & 42,6 & 1333,3 & 4,4 \\
\hline
\end{tabular}

* Розроблено за даними Державної служби статистики України [1].

${ }^{1}$ Дані наведено без урахування тимчасово окупованої території Автономної Республіки Крим, м. Севастополя та частини тимчасово окупованих територій у Донецькій та Луганській областях.

Така ситуація негативно позначається на позиціях України в різноманітних міжнародних рейтингах.

Лідером за більшістю з проаналізованих показників традиційно було м. Київ.

Щодо Волинської області, то динаміка соціально-економічних показників показала (рис. 1-2):

1) щорічний ріст ВРП у розрахунку на одну особу в 2015-2017 роках, хоча темпи росту показника були недостатніми, адже його рівень був нижчим, ніж середнє значення в Україні. Але, що позитивно, відмітилось скорочення розриву між рівнем даного показника у Волинській області та середнім його значенням за регіонами України. Станом на 2017 рік ВРП у розрахунку на одну особу у Волинській області становив 20,9\% від максимального значення за регіонами України;

2) порівняно нижчий рівень життя у Волинській області, адже у 2017-2019 роках спостерігалось перевищення рівня індексу споживчих цін в регіоні над середнім рівнем в Україні;

3) низький рівень інвестування в основний капітал, адже обсяги капітальних інвестиції на одну особу у Волинській області у 2016-2018 роках у порівнянні 3 середніми значення в Україні зменшувались та їх співвідношення становило відповідно 0,73, 0,64 і 0,61. Рівень диференціації регіонів України за даним показником зростав. Збільшувався і розрив в значеннях показника у Волинській області та регіона-лідера (м. Київ). Так, обсяги капітальних інвестиції на одну особу у Волинській області щодо максимального значення в країні становили відповідно 16,6\%, 14,4\% і 12,2\%. При цьому, за роками збільшився розмах варіації показника у Волинській області 3 
мінімальним значенням показника в Україні, що, основним чином, було причиною зниження мінімального рівня даного показника в регіонах країни;

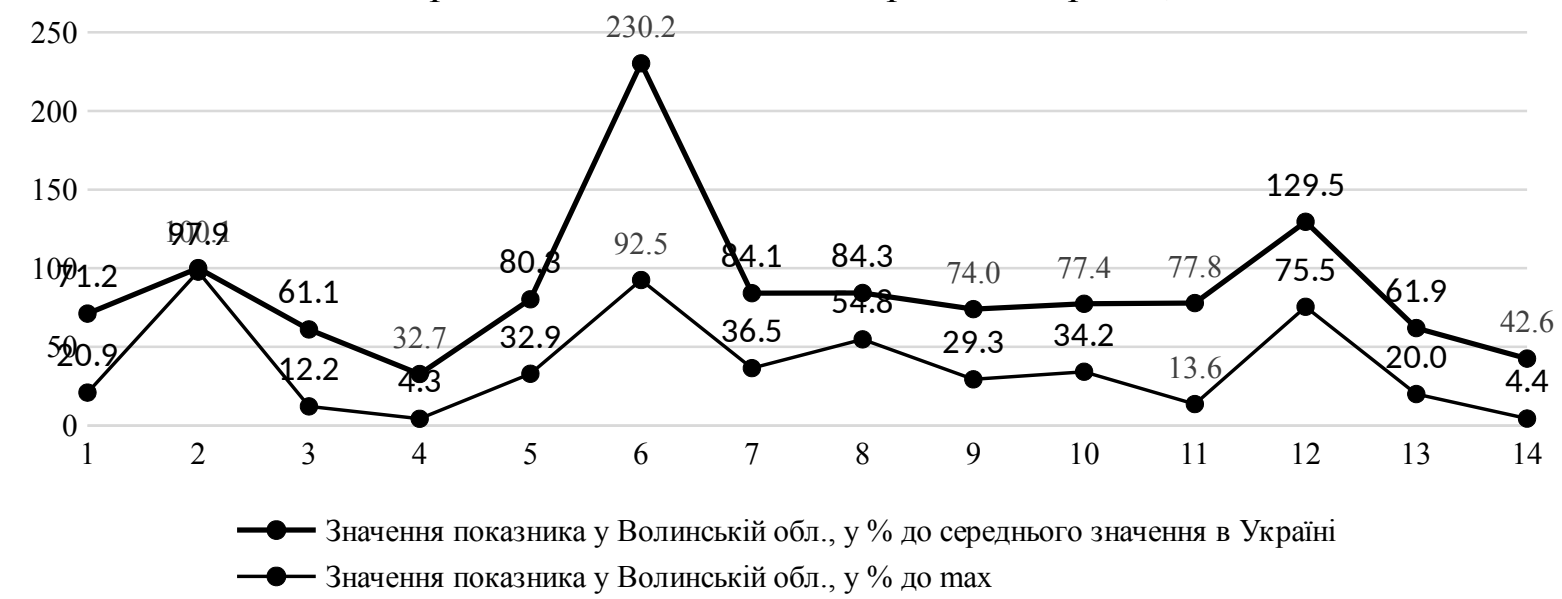

Умовні позначення. По шкалі ОХ відображено показники, найменування яких відповідає їх порядковому номеру у таблиці 1.

Рис. 1. Рівень основних показників соціально-економічного розвитку Волинської області щодо середнього та максимального їх значення в Україні в 2018 році

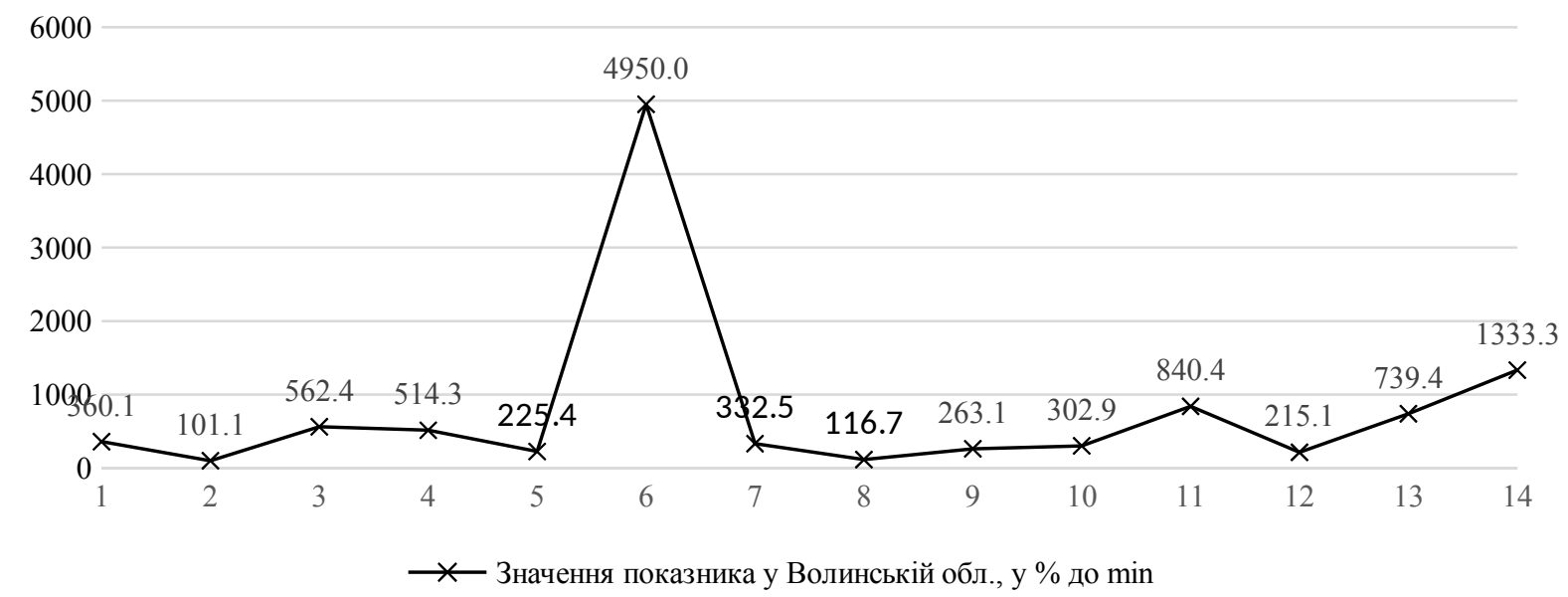

Умовні позначення. По шкалі ОХ відображено показники, найменування яких відповідає їх порядковому номеру у таблиці 1 .

Рис. 2. Рівень основних показників соціально-економічного розвитку Волинської області щодо мінімального їх значення в Україні в 2018 році

4) незначні обсяги прямих інвестицій в економіці регіону - приблизно $32 \%$ від середнього значення в Україні та 4\% від максимального значення в країні, що засвідчує низький рівень інвестиційної привабливості Волинської області та низький рівень зацікавленості іноземних інвесторів у вкладенні коштів в її економіку;

5) порівняно низький рівень фінансової спроможності населення регіону, адже хоча й обсяги наявного доходу населення у розрахунку на одну особу у 2016-2018 роках щорічно підвищувались, проте вони становили лише трохи більше, ніж 80\% від середнього в Україні значення та орієнтовно 32\% від максимального в країні рівня;

6) значну частку населення із середньодушовими еквівалентними грошовими доходами на місяць нижче прожиткового мінімуму, хоча і спостерігалось щорічне іiі зменшення в аналізованому періоді: із 23,5\% у 2016 році (максимальне значення в Україні) до 9,9\% у 2018 році (для порівняння: максимальне значення в 
Україні - 10,7\%, а мінімальне - 0,2\%);

7) нижчий від середнього значення в Україні рівень витрат населення Волинської області у розрахунку на одну особу, що хоч і перевищував мінімальне за регіонами держави значення у понад 3 рази, але у 2018 становив лише 84,1\% від середнього в країні значення і $36,1 \%$ від максимального за регіонами значення;

8) скорочення розриву між рівнем середньомісячної номінальної заробітної плати найманих працівників у Волинській області, середнім та максимальним значеннями в державі. Хоча, станом на грудень 2019 року середньомісячна номінальна заробітна плата найманих працівників у Волинській області становила 84,3\% від середнього значення в Україні, 54,8\% від максимального значення в країні та була на рівні 116,7\% від мінімального значення в країні;

9) близьку до мінімального в Україні рівня забезпеченість населення регіону житлом, що не перевищувала 66\% максимального в країні значення;

10) недостатні темпи росту обсягів доходів місцевих бюджетів (без міжбюджетних трансфертів) Волинської області, обсяги яких станом на 2018 рік хоча i перевищували мінімальне значення в країні у понад 3 рази, але були меншими за середнє значення в Україні $(77,4 \%$ від середнього значення в країні) та становили $34,2 \%$ від максимального значення в країні;

11) недостатні темпи росту обсягів доходів суб'єктів господарювання регіону, обсяги яких станом на 2018 рік хоча і перевищували мінімальне значення в країні у понад 8 разів, але були меншими за середнє значення в Україні на 22,2\% та становили лише 13,6\% від максимального значення в країні;

12) вищий, ніж в середньому в Україні рівень безробіття населення (за методологією МОП) у віці 15-70 років, що майже у 2 рази перевищує мінімальне значення в Україні;

13) зниження рівня експортного потенціалу регіону щодо середньоукраїнського рівня. Обсяги експорту з Волинської області у 2016 році становили 68,7\% від середнього в Україні значення, а у 2018 році - 61,9\%. Разом 3 тим, обсяги експорту з Волинської області у 2016 році у понад 4 рази перевищували мінімальне значення такого показника за регіонами України, а у 2018 році - у понад 7 разів. Обсяги експорту з Волинської області щодо максимального значення у 20172018 роках становили $20,0 \%$;

14) недостатню інноваційну активність підприємств регіону, адже обсяги інноваційних витрат у розрахунку на одне підприємство у Волинській області у 20162018 роках становили відповідно 28,2\%, 108,1\% і 42,6\% від середнього значення в Україні й відповідно 4,3\%, 26,1\% і 4,4\% від максимального значення в країні.

Таким чином, можемо зробити висновок, що Волинська область $є$ регіоном 3 середнім рівнем соціально-економічного розвитку 3 тенденцією до його зниження. Треба зауважити, що високий рівень регіональної соціально-економічної диференціації в Україні є причиною розбалансованості національної економіки та середні значення показників соціально-економічного розвитку регіонів $\epsilon$ недостатніми для капіталізації економіки, забезпечення належного рівня добробуту й якості життя населення.

Поглиблюючи аналітичне дослідження соціально-економічного розвитку й з'ясування сильних сторін і втрачених можливостей Волинської області, проаналізуємо iї місце у різноманітних регіональних рейтингах та проведемо порівняльну оцінку рівня досягнутих регіоном соціально-економічних показників.

Згідно результатів моніторингу соціально-економічного розвитку регіонів, оприлюднених Міністерством розвитку громад та територій, Волинська область у такому рейтингу у 2016 році посідала 9 місце, у 2017 році - 10 місце, а у 2018 році 14 місце (табл. 2) [2-5]. Найбільш сприятлива ситуація у 2015-2018 роках у Волинській 
області спостерігається за такими напрямами моніторингу, як «Соціальний захист та безпека» (не нижче 3-го місця) й «Відновлювана енергетика та енергоефективність» (4те місце у 2018 році). У Волинській області в досліджуваному періоді ситуація поліпшилась за напрямом «Розвиток малого та середнього підприємництва», за яким у 2015 і 2016 роках регіон був на 19 місці, а у 2017 і 2018 роках - відповідно на 11 і 9 місцях. Також Волинській області вдалось посилити позиції за напрямом «Раціональне природокористування та якість довкілля», за яким у 2015 році регіон був на 25 місці, а до 2018 року досягнув 16 місця. Відносна стабільність, хоча й низькі позиції Волинської області у рейтингу спостерігається за таким напрямом моніторингу, як «Доступність та якість послуг у сфері охорони здоров'я». Вузькі місця для Волинської області виявились за такими напрямами моніторингу, як «Доступність та якість послуг у сфері освіти», «Фінансова самодостатність» та «Ефективність ринку праці», за якими у 2018 році області була відповідно на 22, 25 і 18 місцях. За напрямом моніторингу «Економічна ефективність» Волинська область 3 8-го місця у рейтингу у 2015 році опустилась до 18-го місця у 2016 році та до 19-го місця у 2017-2018 роках. За напрямом моніторингу «Інвестиційно-інноваційний розвиток та зовнішньоекономічна співпраця» Волинська область 3 8-го місця у рейтингу у 2015 році опустилась до 21-го місця у 2017 році, а у 2018 році дещо посилила свої позиції та зайняла 17-те місця.

Таблиця 2

Результати моніторингу соціально-економічного розвитку Волинської області серед регіонів України (на основі результатів моніторингу [2-5])

\begin{tabular}{|c|c|c|c|c|c|c|c|}
\hline \multirow{2}{*}{$\begin{array}{l}\text { Напрями моніторингу соціально- } \\
\text { економічного розвитку регіону }\end{array}$} & \multicolumn{4}{|c|}{$\begin{array}{l}\text { Місце Волинської області за } \\
\text { напрямами моніторингу }\end{array}$} & \multirow{2}{*}{$\begin{array}{c}\text { Місце } \\
\text { лідера } \\
\text { рейтингу } \\
\text { - м. Київ } \\
\text { (2018 р.) }\end{array}$} & \multirow{2}{*}{\begin{tabular}{c|} 
Місце \\
аутсайдера \\
рейтингу - \\
Луганська \\
обл. (2018 р.)
\end{tabular}} & \multirow{2}{*}{$\begin{array}{c}\text { Регіони-лідери / } \\
\text { регіони- } \\
\text { аутсайдери } \\
\text { секторальних } \\
\text { рейтингів }\end{array}$} \\
\hline & $2015 \mathrm{p}$. & $2016 \mathrm{p}$. & $2017 \mathrm{p}$. & $2018 \mathrm{p}$. & & & \\
\hline $\begin{array}{l}\text { 1. Економічна та соціальна } \\
\text { згуртованість }\end{array}$ & 18 & 14 & 11 & 13 & 1 & 25 & $\begin{array}{c}\text { м. Київ / } \\
\text { Луганська обл. }\end{array}$ \\
\hline 2. Економічна ефективність & 8 & 18 & 19 & 19 & 5 & 25 & $\begin{array}{l}\text { Вінницька обл. / } \\
\text { Луганська обл. }\end{array}$ \\
\hline $\begin{array}{l}\text { 3. Інвестиційно-інноваційний } \\
\text { розвиток та зовнішньоекономічна } \\
\text { співпраця }\end{array}$ & 8 & 20 & 21 & 17 & 1 & 25 & $\begin{array}{c}\text { м. Київ / } \\
\text { Луганська обл. }\end{array}$ \\
\hline 4. Фінансова самодостатність & 10 & 19 & 5 & 25 & 1 & 10 & $\begin{array}{c}\text { м. Київ / } \\
\text { Волинська обл. }\end{array}$ \\
\hline $\begin{array}{l}\text { 5. Розвиток малого та середнього } \\
\text { підприємництва }\end{array}$ & 19 & 19 & 11 & 9 & 1 & 22 & $\begin{array}{c}\text { м. Київ / } \\
\text { Донецька обл. }\end{array}$ \\
\hline 6. Ефективність ринку праці & 12 & 20 & 19 & 18 & 3 & 25 & $\begin{array}{l}\text { Київська обл. / } \\
\text { Луганська обл. }\end{array}$ \\
\hline 7. Розвиток інфраструктури & 13 & 17 & 19 & 9 & 25 & 21 & $\begin{array}{l}\text { Чернівецька обл. } \\
\text { / м. Київ }\end{array}$ \\
\hline $\begin{array}{l}\text { 8. Відновлювана енергетика та } \\
\text { енергоефективність }\end{array}$ & 9 & 1 & 3 & 4 & 24 & 23 & $\begin{array}{c}\text { Рівненська обл. / } \\
\text { Донецька обл. }\end{array}$ \\
\hline $\begin{array}{l}\text { 9. Доступність та якість послуг у сфері } \\
\text { освіти }\end{array}$ & 20 & 18 & 19 & 22 & 2 & 8 & $\begin{array}{l}\text { Харківська обл. / } \\
\text { Закарпатська } \\
\text { обл. } \\
\end{array}$ \\
\hline $\begin{array}{l}\text { 10. Доступність та якість послуг у } \\
\text { сфері охорони здоров'я }\end{array}$ & 8 & 8 & 8 & 9 & 1 & - & $\begin{array}{c}\text { м. Київ / } \\
23 \text { місце - } \\
\text { Чернігівська } \\
\text { обл. } \\
\end{array}$ \\
\hline 11. Соціальний захист та безпека & 2 & 2 & 1 & 3 & 18 & 23 & $\begin{array}{c}\text { Рівненська обл. / } \\
\text { Чернігівська } \\
\text { обл. }\end{array}$ \\
\hline $\begin{array}{l}\text { 12. Раціональне природокористування } \\
\text { та якість довкілля }\end{array}$ & 25 & 21 & 23 & 16 & 1 & 23 & $\begin{array}{c}\text { м. Київ / } \\
\text { Донецька обл. }\end{array}$ \\
\hline Загальне місие регіону & 12 & 9 & 10 & 14 & $\begin{array}{c}1 \\
(2015- \\
2017 \text { р.: } \\
1 \text { місце) }\end{array}$ & $\begin{array}{c}25 \\
\text { (2015-2017 } \\
\text { р.: 25 місце) }\end{array}$ & $\begin{array}{c}\text { м. Київ / } \\
\text { Луганська обл. }\end{array}$ \\
\hline
\end{tabular}


Трійка лідерів рейтингу соціально-економічного розвитку регіонів України у 2017 і 2018 роках була незмінною та до неї належали м. Київ, Харківська та Рівненська області. На 4-му та 5-му місцях рейтингу в 2017 році відповідно були такі регіони України, як Дніпропетровська та Чернівецька області, а у 2018 році - Вінницька та Дніпропетровська області.

Аутсайдерами такого рейтингу соціально-економічного розвитку регіонів України у 2017-2018 роках були Миколаївська, Одеська, Чернігівська, Донецька та Луганська області.

Результати такого моніторингу слугують індикаторами ефективності управлінських рішень на регіональному та державному рівнях. Таким чином, прийняті у Волинській області управлінські рішення були недостатньо ефективними й дієвими, існує потреба їх коригування та і загалом оновлення моделей стратегічного планування й управління в регіоні.

Результати регіонального рейтингу ведення бізнесу (Regional Doing Business Ranking), який характеризує легкість ведення бізнесу в регіонах України, демонструють, що у 2018 році Волинська область посідала 8-ме місце, набравши 305 балів 3 максимально можливих 600 (табл. 3) [6]. Такі результати свідчать про ряд проблемних моментів взаємодії суб'єктів господарювання із місцевими органами влади, адже фактично Волинська область набрала лише 50,8\% балів 3 можливих і лише за рахунок того, що в інших регіонах держави ситуація була ще гіршою, зайняла 8-у позицію в такому рейтингу.

Таблиця 3

Місце Волинської області у регіональному рейтингу ведення бізнесу (Doing Business) у 2018 році (на основі результатів рейтингу [6])

\begin{tabular}{|c|c|c|c|c|c|c|}
\hline \multirow{2}{*}{$\begin{array}{c}\text { Компоненти легкості ведення бізнесу } \\
\text { (критерії оцінювання) }\end{array}$} & \multicolumn{2}{|c|}{ Волинська обл. } & \multirow{2}{*}{$\begin{array}{l}\text { Регіони-лідери } \\
\text { секторальних } \\
\text { рейтингів }\end{array}$} & \multirow{2}{*}{$\begin{array}{c}\text { Регіони- } \\
\text { аутсайдери } \\
\text { секторальних } \\
\text { рейтингів }\end{array}$} & \multirow{2}{*}{\begin{tabular}{|c|} 
Бали \\
лідера \\
рейтингу - \\
Вінницька \\
обл.
\end{tabular}} & \multirow{2}{*}{$\begin{array}{c}\text { Бали } \\
\text { аутсайдера } \\
\text { рейтингу - } \\
\text { Чернівецька } \\
\text { обл. }\end{array}$} \\
\hline & Бали & Рейтинг & & & & \\
\hline $\begin{array}{l}\text { 1. Створення підприємства - вимірює } \\
\begin{array}{ll}\text { простоту започаткування } \\
(\max =100 \text { балів) }\end{array} \\
\end{array}$ & 82 & $9-10$ & $\begin{array}{l}\text { Житомирська обл. } \\
\text { (87) }\end{array}$ & $\begin{array}{l}\text { Луганська } \\
\text { обл. (62) }\end{array}$ & 86 & 84 \\
\hline \begin{tabular}{|lrr|}
2. & Одержання & \multicolumn{2}{c}{ дозволів } \\
будівництво - & вимірює \\
оформлення процесу & будівництва \\
(max=100 балів) & \\
\end{tabular} & 49 & $10-11$ & $\begin{array}{c}\text { Чернігівська, } \\
\text { Київська обл. (64) }\end{array}$ & $\begin{array}{l}\text { Полтавська } \\
\text { обл. (32) }\end{array}$ & 53 & 41 \\
\hline $\begin{array}{l}\text { 3. Оформлення земельної ділянки - } \\
\text { вимірює простоту оформлення та } \\
\text { отримання права оренди земельної } \\
\text { ділянки (max }=100 \text { балів) }\end{array}$ & 52 & 7 & $\begin{array}{l}\text { Вінницька обл. } \\
\text { (71) }\end{array}$ & $\begin{array}{c}\text { Запорізька, } \\
\text { Чернівецька } \\
\text { обл. (21) }\end{array}$ & 71 & 21 \\
\hline $\begin{array}{l}\text { 4. Приєднання до електромереж - } \\
\text { вимірює простоту приєднання нового } \\
\text { об'єкта будівництва до електромереж } \\
\text { (max=100 балів) }\end{array}$ & 71 & $1-2$ & $\begin{array}{l}\text { Житомирська, } \\
\text { Волинська обл. } \\
\text { (71) }\end{array}$ & $\begin{array}{c}\text { Київська обл. } \\
\text { (45) }\end{array}$ & 67 & 48 \\
\hline \begin{tabular}{|lrr} 
5. Сплата місцевих & податків \\
вимірює & тягар, що накладається на \\
бізнес & місцевими & податками \\
$(\max =100$ & балів) & \\
\end{tabular} & 33 & $15-18$ & $\begin{array}{c}\text { Харківська, } \\
\text { Донецька обл. (45) }\end{array}$ & $\begin{array}{l}\text { Чернігівська } \\
\text { обл. (23) }\end{array}$ & 35 & 37 \\
\hline $\begin{array}{l}\text { 6. Електронні сервіси - вимірює обсяг } \\
\text { адміністративних послуг та } \\
\text { дозвільних процедур, які можна } \\
\text { отримати або пройти за допомогою } \\
\text { використання мережі Інтернет у } \\
\text { найбільшому місті регіону/обласному } \\
\text { центрі (max=100 балів) }\end{array}$ & 18 & $13-15$ & $\begin{array}{c}\text { Дніпропетровська } \\
\text { обл. (45) }\end{array}$ & $\begin{array}{l}\text { Черкаська } \\
\text { обл. (14) }\end{array}$ & 22 & 16 \\
\hline $\begin{array}{c}\text { Узагальнюючі результати регіону } \\
\text { (тах =600 балів) }\end{array}$ & 305 & 8 & - & - & 334 & 247 \\
\hline
\end{tabular}


Загальна кількість балів за Волинською областю у регіональному рейтингу ведення бізнесу становить $123,5 \%$ від кількості балів регіона-аутсайдера такого рейтингу - Чернівецької області (247 балів) та 91,31\% від кількості балів регіона-лідера такого рейтингу - Вінницької області (334 балів), що підтверджує недостатньо сприятливі умови й неналежний бізнес-клімат для розвитку малого та середнього підприємництва в регіонах України загалом.

Згідно результатів рейтингу інвестиційної ефективності областей України, оприлюднених Рейтинговим агентством «Євро-Рейтинг», Волинська область значно поліпшила свої позиції порівняно з 2016 роком та у IV кварталі 2018 року посідала 3-є місце, у I кварталі 2019 року - 2-е місце, проте у II кварталі 2019 року - 7-е місце (табл. 4, рис. 3) [7].

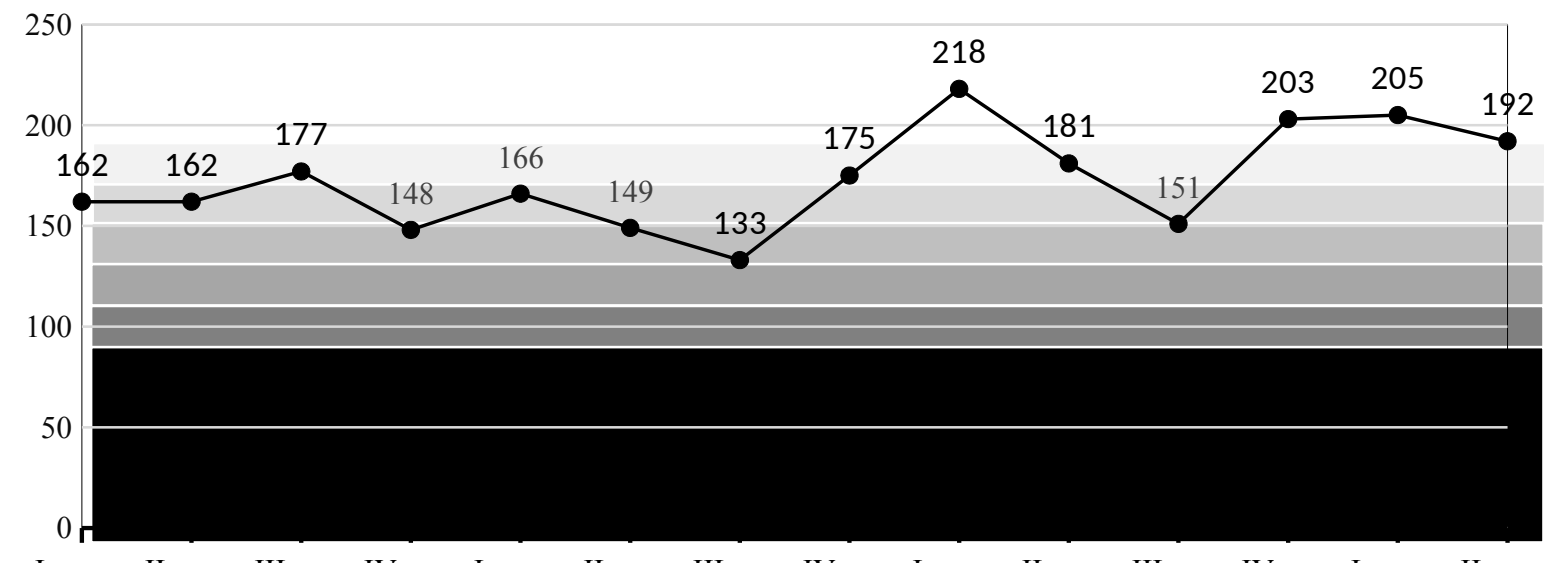

I кв. $\quad$ II кв. $\quad$ III кв. IV кв. I кв. $\quad$ II кв. III кв. IV кв. $\quad$ I кв. $\quad$ II кв. $\quad$ III кв. IV кв. I кв. II кв. 2016 p. 2016 p. 2016 p. 2016 p. 2017 p. 2017 p. 2017 p. 2017 p. 2018 p. 2018 p. 2018 p. 2018 p. 2019 p. 2019 p.

\begin{tabular}{|c|c|c|c|c|c|c|c|}
\hline Бали & $<101$ & $101-120$ & $121-140$ & $141-160$ & $161-180$ & $181-200$ & $>200$ \\
\hline $\begin{array}{c}\text { Рівень } \\
\text { рейтингу }\end{array}$ & Мінімальний & Низький & $\begin{array}{c}\text { Нижче } \\
\text { середнього }\end{array}$ & Середній & $\begin{array}{c}\text { Вище } \\
\text { середнього }\end{array}$ & Високий & Максимальний \\
\hline
\end{tabular}

Рис. 3. Волинська область у рейтингу інвестиційної ефективності областей України (на основі [7])

Таблиця 4

Місце Волинської області у рейтингу інвестиційної ефективності областей України (на основі [7])

\begin{tabular}{|c|c|c|c|c|}
\hline \multirow{2}{*}{ Період } & \multicolumn{2}{|c|}{ Волинська обл. } & \multirow{2}{*}{$\begin{array}{c}\text { Бали регіона-лідера } \\
\text { рейтингу }\end{array}$} & \multirow{2}{*}{$\begin{array}{c}\text { Бали регіона-аутсайдера } \\
\text { рейтингу }\end{array}$} \\
\hline & Бали & Рейтинг & & \\
\hline І кв. 2016 p. & 162 & $9-10$ & 240 (Харківська обл.) & 102 (Закарпатська обл.) \\
\hline II кв. 2016 p. & 162 & 9 & 224 (Одеська обл.) & 102 (Рівненська обл.) \\
\hline III кв. 2016 p. & 177 & 8 & 224 (Київська обл.) & 88 (Чернівецька обл.) \\
\hline IV кв. 2016 p. & 148 & 15 & 216 (Київська обл.) & 94 (Рівненська обл.) \\
\hline I кв. 2017 p. & 166 & 11 & 246 (Полтавська обл.) & 93 (Херсонська обл.) \\
\hline II кв. 2017 p. & 149 & 17 & 210 (Харківська обл.) & 95 (Чернівецька обл.) \\
\hline III кв. 2017 p. & 133 & 17 & 219 (Полтавська обл.) & 125 (Закарпатська обл.) \\
\hline IV кв. 2017 p. & 175 & $8-9$ & 225 (Полтавська обл.) & 117 (Чернівецька обл.) \\
\hline I кв. 2018 р. & 218 & 2 & 236 (Дніпропетровська обл.) & 72 (Сумська обл.) \\
\hline II кв. 2018 p. & 181 & 8 & 234 (Київська обл.) & 96 (Чернівецька обл.) \\
\hline III кв. 2018 p. & 151 & 12 & 223 (Київська обл.) & 107 (Херсонська обл.) \\
\hline IV кв. 2018 p. & 203 & 3 & 242 (Київська обл.) & 90 (Херсонська обл.) \\
\hline I кв. 2019 p & 205 & 2 & 244 (Київська обл.) & 114 (Сумська обл.) \\
\hline II кв. 2019 p. & 192 & 7 & 223 (Київська обл.) & 109 (Чернігівська обл.) \\
\hline
\end{tabular}


Рівень інвестиційної ефективності Волинської області у IV кварталі 2018 року та I кварталі 2019 року згідно пропонованого Рейтинговим агентством «Євро-Рейтинг» ранжування належав до максимального рівня, а у II кварталі 2019 року - до високого. Станом на II квартал 2019 року кількість балів Волинської області у рейтингу інвестиційної ефективності становила 192, що становить 86,1\% від кількості балів регіона-лідера та на 76,1\% перевищує кількість балів регіона-аутсайдера. Високі бали Волинської області в попередні періоди, зокрема у I кварталі 2018 року (218 балів) свідчать про потенціал регіону для підвищення інвестиційної ефективності.

У рейтингу областей України за успіхами в євроінтеграції, підготовленому аналітиками Центру «Нова Європа» у співпраці з Урядовим офісом координації європейської та євроатлантичної інтеграції, Волинська область увійшла до шестірки регіонів із найвищими балами [8]. Однак, зважаючи на загальну кількість балів отриманих у процесі оцінки 8-ми сфер за 34 індикаторами, Волинська область набрала лише 126,22 бали 3 максимальних 248 балів, тобто 50,9\% від максимально можливого рівня (табл. 5). Лідируючі позиції у даному рейтингу займає Львівська область із кількістю балів 171,15 (69,0\% від максимально можливих). Таким чином, реальна ситуація засвідчує в цілому низьку активність регіонів України у процесах європейської інтеграції, нереалізованість потенціалу Волинської області у даному напрямі та упущені нею можливості на рівні близько 50\%.

Таблиця 5

Місце Волинської області у рейтингу європейської інтеграції областей станом на 2019 рік (на основі [8])

\begin{tabular}{|c|c|c|c|c|c|c|c|c|}
\hline \multirow[t]{2}{*}{ Сфери оцінки } & \multicolumn{2}{|c|}{ Волинська обл. } & \multicolumn{2}{|c|}{$\begin{array}{c}\text { Регіон-лідер } \\
\text { рейтингу - } \\
\text { Львівська обл. } \\
\end{array}$} & \multicolumn{2}{|c|}{$\begin{array}{c}\text { Регіон-аутсайдер } \\
\text { рейтингу - } \\
\text { Луганська обл. }\end{array}$} & \multirow{2}{*}{$\begin{array}{c}\text { Лідери } \\
\text { секторальних } \\
\text { рейтингів }\end{array}$} & \multirow{2}{*}{$\begin{array}{c}\text { Аутсайдери } \\
\text { секторальних } \\
\text { рейтингів }\end{array}$} \\
\hline & Бали & Рейтинг & Бали & Рейтинг & Бали & Рейтинг & & \\
\hline $\begin{array}{l}\text { 1. Економічна інтеграція } \\
(\mathrm{max}=50 \text { балів) }\end{array}$ & 25,3 & 11 & 34,47 & 2 & 23,65 & 13 & $\begin{array}{c}\text { Івано-Франківська } \\
\text { обл. }(41,45)\end{array}$ & $\begin{array}{c}\text { Кіровоградська } \\
\text { обл. }(8,62) \\
\end{array}$ \\
\hline $\begin{array}{l}\text { 2. Інфраструктура } \\
(\max =27 \text { балів) }\end{array}$ & 10,23 & 13 & 21,5 & 2 & 3,79 & 25 & $\begin{array}{c}\text { Одеська обл. } \\
(22,97)\end{array}$ & $\begin{array}{c}\text { Луганська обл. } \\
(3,79)\end{array}$ \\
\hline $\begin{array}{l}\text { 3. Локальна демократія } \\
\text { та підзвітність (max=34 } \\
\text { балів) }\end{array}$ & 22,62 & 3 & 18,37 & 10 & 17,01 & 13 & $\begin{array}{c}\text { Дніпропетровська } \\
\text { обл. }(26,54)\end{array}$ & м. Київ $(4,76)$ \\
\hline $\begin{array}{l}\text { 4. Освітня, наукова та } \\
\text { культурна інтеграція } \\
\text { (max=42 балів) }\end{array}$ & 14,14 & 18 & 36,59 & 1 & 7,76 & 25 & $\begin{array}{l}\text { Львівська обл. } \\
(36,59)\end{array}$ & $\begin{array}{l}\text { Луганська обл. } \\
(7,76)\end{array}$ \\
\hline $\begin{array}{l}\text { 5. Екологічна та } \\
\text { енергетична політика } \\
(\max =28 \text { балів) }\end{array}$ & 10,93 & 15 & 20,72 & 1 & 5,83 & 23 & $\begin{array}{l}\text { Львівська обл. } \\
(20,72)\end{array}$ & м. Київ $(2,03)$ \\
\hline $\begin{array}{l}\text { 6. Гендерна рівність } \\
(\max =20 \text { балів) }\end{array}$ & 13,15 & 5 & 13,75 & 3 & 10,45 & 11 & $\begin{array}{c}\text { Чернівецька обл. } \\
(14,85)\end{array}$ & $\begin{array}{l}\text { Миколаївська } \\
\text { обл. }(3,65) \\
\end{array}$ \\
\hline $\begin{array}{l}\text { 7. Комунікація інтеграції } \\
(\mathrm{max}=27 \text { балів) }\end{array}$ & 15,46 & 6 & 20,97 & 1 & 5,25 & 25 & $\begin{array}{l}\text { Львівська обл. } \\
(20,97)\end{array}$ & $\begin{array}{c}\text { Луганська обл. } \\
(5,25)\end{array}$ \\
\hline $\begin{array}{l}\text { 8. Ширше партнерство } \\
(\mathrm{max}=20 \text { балів) } \\
\end{array}$ & 14,39 & 2 & 5,8 & 18 & 2,59 & 25 & м. Київ $(14,45)$ & $\begin{array}{c}\text { Луганська обл. } \\
(2,59)\end{array}$ \\
\hline $\begin{array}{c}\text { Узагальнюючі } \\
\text { результати рейтингу } \\
\text { (тах=248 балів) }\end{array}$ & 126,22 & 6 & 171,15 & 1 & 76,33 & 25 & - & - \\
\hline
\end{tabular}

За результатами моніторингу процесу децентралізації та реформування місцевого самоврядування Міністерства розвитку громад та територій України [9], Волинська область у рейтингу областей щодо формування спроможних громад станом на 10 січня 2020 рік зайняла 6 місце, поступаючись Житомирський, Дніпропетровський, Чернігівській, Хмельницькій та Запорізький областям (табл. 6). Схвально та позитивно, що у Волинській області та ще в 7 інших областях України (Дніпропетровській, Донецькій, Запорізькій, Луганській, Рівненській, Харківській і 
Хмельницькій областях) $є$ перспективні плани формування територій громад, затверджені Урядом, які покривають 100\% їх території.

Таблиця 6

Місце Волинської області у рейтингу областей України щодо формування спроможних громад станом на 10 січня 2020 рік (на основі [9])

\begin{tabular}{|c|c|c|}
\hline Параметри оцінювання & $\begin{array}{c}\text { 3начення параметра } \\
(2015-2019 \text { рp.) }\end{array}$ & Рейтинг \\
\hline $\begin{array}{l}\text { 1. Кількість населення спроможних громад (об’єднані територіальні громади - ОТГ, міста } \\
\text { обласного значення - МОЗ), тис. осіб }\end{array}$ & 773 & 10 \\
\hline 2. Площа спроможних громад (ОТГ, МОЗ), км² & 12137 & 6 \\
\hline 3. Кількість територіальних громад, що не об’єдналися та не приєдналися & 167 & 6 \\
\hline $\begin{array}{l}\text { 4. Кількість районів в області, де не розпочато процес добровільного об’єднання } \\
\text { (приєднання) територіальних громад }\end{array}$ & 0 & 1 \\
\hline 5. Кількість ОТГ, з чисельністю жителів менше 5 тис. осіб & 19 & 12 \\
\hline 6. Кількість ОТГ з адміністративними центрами у містах обласного значення & 4 & 6 \\
\hline $\begin{array}{l}\text { 7. Покриття перспективними планами (ПП): кількість ОТГ у ПП, затверджених } \\
\text { Урядом / кількість ТГ, не охоплених ПП / \% ТГ від їх загальної кількості, } \\
\text { неохоплених ПП }\end{array}$ & $73 / 0 / 0$ & 1 \\
\hline Загальний рейтинг & - & 6 \\
\hline
\end{tabular}

Висновки. Отже, розглянуті рейтинги достатньо переконливо демонструють місце Волинської області в соціально-економічному розвитку України. Загалом Волинська область згідно розглянутих регіональних рейтингів займає в середньому вищі від середнього позиції серед регіонів України. Разом 3 тим, результати проведеного аналітичного дослідження продемонстрували нестабільність соціальноекономічного розвитку Волинської області та нестійкі ऑiі позиції в рейтингових таблицях.

Щодо перспектив подальших досліджень, то результати проведеного аналітичного дослідження параметричних характеристик й індикаторів соціальноекономічного розвитку Волинської області у площині соціально-економічного розвитку України стимулюють пошук реальних причин і механізмів подолання проблемних моментів в розвитку регіону. Проведене дослідження є вихідним моментом наукових пошуків стратегічних пріоритетів i векторів соціально-економічного розвитку Волинської області, розробки обгрунтованої стратегії розвитку регіону, прийняття раціональних управлінських тактичних і стратегічних рішень.

\section{Список бібліографічного опису:}

1. Державна служба статистики України: офіційний веб-сайт. URL: http://www.ukrstat.gov.ua (дата звернення 20.02.2020).

2. Моніторинг соціально-економічного розвитку регіонів за січень-грудень 2015 року. URL: https://www.minregion.gov.ua/wpcontent/uploads/2016/03/Reytingova-otsinka-za-sichen-gruden-2015-roku-prezentatsiyni-materiali.pdf (дата звернення 20.02.2020).

3. Моніторинг соціально-економічного розвитку регіонів за 2016 рік. URL: https://www.minregion.gov.ua/wp-content/uploads/2017/05/Reytingova-otsinka-za-2016-rik-prezentatsiyni-materiali.pdf (дата звернення 20.02.2020)

4. Моніторинг соціально-економічного розвитку регіонів за 2017 рік. URL: https://www.minregion.gov.ua/wp-content/uploads/2018/05/Reytingova-otsinka-za-2017-rik-prezentatsiyni-materiali.pdf (дата звернення 20.02.2020).

5. Моніторинг соціально-економічного розвитку регіонів за 2018 рік. URL: https:/www.minregion.gov.ua/wp-content/uploads/2019/05/Reytingova-otsinka-za-2018-rik-prezentatsiyni-materiali.pdf (дата звернення 20.02.2020).

6. Рейтинг ведення бізнесу у регіонах 2018 (Regional Doing Business Ranking 2018). Офіс ефективного регулювання (BRDO); Спілка українських підприємців (СУП). URL: http://rdb.brdo.com.ua http://rdb.brdo.com.ua (дата звернення 20.02.2020).

7. Рейтинг инвестиционной эффективности областей. URL: http://euro-rating.com.ua/regiony/rejting-list/rejting-list-oblastej/ (дата звернення 20.02.2020).

8. Євромапа України. Рейтинг європейської інтеграції областей. Київ, Центр «Нова Європа», 2019. URL: http://neweurope.org.ua/wp-content/uploads/2019/11/Euromap-ukr-web.pdf (дата звернення 20.02.2020).

9. Моніторинг процесу децентралізації та реформування місцевого самоврядування (станом на 10 січня 2020 р.). Міністерство розвитку громад та територій України. URL: https://ecentralization.gov.ua/uploads/library/file/526/10.01.2020.pdf (дата звернення 20.02.2020).

\section{References:}

1. Ofitsiinyi veb-sait Derzhavnoi sluzhby statystyky Ukrainy [Official web-site of the State Statistics Service of Ukraine]. Retrieved from http://www.ukrstat.gov.ua (accessed 20 February 2019). 
2. Monitorynh sotsialno-ekonomichnoho rozvytku rehioniv za sichen-hruden 2015 roku [Monitoring the socio-economic development of regions in 2015]. Retrieved from https://www.minregion.gov.ua/wp-content/uploads/2016/03/Reytingova-otsinka-za-sichen-gruden-2015roku-prezentatsiyni-materiali.pdf (accessed 20 February 2019). [in Ukrainian].

3. Monitorynh sotsialno-ekonomichnoho rozvytku rehioniv za 2016 rik [Monitoring the socio-economic development of regions in 2016]. Retrieved from https://www.minregion.gov.ua/wp-content/uploads/2017/05/Reytingova-otsinka-za-2016-rik-prezentatsiyni-materiali.pdf (accessed 20 February 2019). [in Ukrainian].

4. Monitorynh sotsialno-ekonomichnoho rozvytku rehioniv za 2017 rik [Monitoring the socio-economic development of regions in 2017]. Retrieved from https://www.minregion.gov.ua/wp-content/uploads/2018/05/Reytingova-otsinka-za-2017-rik-prezentatsiyni-materiali.pdf (accessed 20 February 2019). [in Ukrainian].

5. Monitorynh sotsialno-ekonomichnoho rozvytku rehioniv za 2018 rik [Monitoring the socio-economic development of regions in 2018]. Retrieved from https://www.minregion.gov.ua/wp-content/uploads/2019/05/Reytingova-otsinka-za-2018-rik-prezentatsiyni-materiali.pdf (accessed 20 February 2019). [in Ukrainian].

6. Reitynh vedennia biznesu u rehionakh 2018 [Regional Doing Business Ranking 2018]. Better Regulation Delivery Office (BRDO); The Union of Ukrainian Entrepreneurs (SUP). Retrieved from http://rdb.brdo.com.ua http://rdb.brdo.com.ua (accessed 20 February 2019). [in Ukrainian].

7. Reyting investitsionnoy effektivnosti oblastey [Regional investment efficiency ranking]. Retrieved from http://euro-rating.com.ua/regiony/rejting-list/rejting-list-oblastej/ (accessed 20 February 2019). [in Russian].

8. Yevromapa Ukrainy. Reitynh yevropeiskoi intehratsii oblastei [The European map of Ukraine. Rating of European Integration of Regions]. (2019). Kyiv: New Europe Center. Retrieved from http://neweurope.org.ua/wp-content/uploads/2019/11/Euromap-ukr-web.pdf (accessed 20 February 2019). [in Ukrainian].

9. Monitorynh protsesu detsentralizatsii ta reformuvannia mistsevoho samovriaduvannia (stanom na 10 sichnia $2020 \mathrm{r}$.) [Monitoring of the process of power decentralisation and local governance reform (10 January 2020)]. Ministry of Development of Communities and Territories of Ukraine. Retrieved from https://decentralization.gov.ua/uploads/library/file/526/10.01.2020.pdf (дата звернення 20.02.2020). (accessed 20 February 2019). [in Ukrainian].

Дата подання публікації 26.03.2020 р.

УДК 338.2:332.12 (1-22)+63(477.82)

Соколова А.О., к.е.н., доцент https://orcid.org/0000-0003-0194-6706

Ратошнюк Т.M., к.е.н., ст. наук. Співробітник https://orcid.org/0000-0002-1097-0874

Sokolova A. Candidate of Economic Sciences, Associate Professor Ratoshnyuk T.M. Candidate of Economics Science, Senior Researcher

\title{
СОЦАЛЬНО-ЕКОНОМІЧНІ НАСЛІДКИ ДЕЦЕНТРАЛІЗАЦЙНИХ ПЕРЕТВОРЕНЬ НА СІЛЬСЬКИХ ТЕРИТОРІЯХ: РЕГІОНАЛЬНИЙ АСПЕКТ
}

\author{
Волинська державна сільськогосподарська дослідна станція НААН Украӥни \\ Інститут сільського господарства Полісся НААН Украӥни
}

Одним 3 основних аспектів аграрної політики України є побудова такої моделі розвитку сільських територій, яка б відповідала стандартам розвиненої європейської країни. Концепт адміністративної децентралізації в Україні ідеологічно сформувався впродовж останніх трьох років після активізації намірів інтегруватися до Європейського Союзу. Процес децентралізації владних повноважень в Україні створив передумови для самостійного соціально-економічного сільського розвитку на базі громад.

Метою даного дослідження $\epsilon$ визначення особливостей здійснення адміністративнотериторіальної реформи на сільських територіях Волинської області та здійснення оцінки сучасного етапу соціально-економічного розвитку об’єднаних територіальних громад 3 метою розробки та обгрунтування науково-організаційних засад та практичних рекомендацій щодо управління соціальноекономічними сільським розвитком регіону. Доведено, що розвиток сільської економіки Волинської області значною мірою залежить від природно-економічних умов, виробничо-ресурсного, фінансового та людського потенціалу й діяльності окремих сільських територіальних громад.

В статті проведено аналіз соціально-демографічної ситуації в області; визначено регіональні особливості перебігу адміністративно-територіальної реформи на сільських територіях Волині; оцінено результати використання бюджетних доходів створених територіальних громад; стан і забезпеченість об'єктами соціальної інфраструктури; ідентифіковано основні проблеми розвитку ОТГ. За допомогою SWOT-аналізу визначено «сильні» та «слабкі сторони» й потенційні можливості та загрози децентралізації для соціально-економічного розвитку сільських територій досліджуваного регіону. 
Ключові слова: сільські територї, децентралізація, об’єднані територіальні громади, сочіально-економічний розвиток.

\section{SOCIO-ECONOMIC CONSEQUENCES OF DECENTRALIZATION TRANSFORMATIONS IN RURAL AREAS: REGIONAL ASPECT}

Volhynia state agricultural experimental station of the National academy of agrarian sciences of Ukraine Institute of Agriculture Polissya National academy of agrarian sciences of Ukraine

One of the main aspects of the agrarian policy of Ukraine is the construction of such a model of rural 